\title{
Corporate Governance and Risk Disclosure: Evidence from Saudi Arabia
}

\author{
Dr. Awad Ibrahim* \\ Lecturer of Accounting and Financial Management \\ University of Portsmouth, UK \\ Email: Awad.Ibrahim@port.ac.uk \\ Dr. Murya Habbash \\ Associate Professor of Accounting \\ King Khalid University, Saudi Arabia \\ Murya@hotmail.com \\ Professor Khaled Hussainey \\ Professor of Accounting and Financial Management \\ University of Portsmouth, UK \\ Khaled.Hussainey@port.ac.uk
}

* Corresponding author 


\begin{abstract}
Purpose: This study investigates the potential influence of corporate governance, ownership structure and corporate characteristics on risk disclosure level, in a developing country, Saudi Arabia, in which there is a lack of research in this area.

Methodology: This study examines 408 annual reports of Saudi non-financial-listed firms during 2012-2015. We apply content and multiple regression analyses and use the number of the risk-related sentences as a proxy for risk disclosure level.

Findings: The results indicate that the mean risk disclosure is 13 sentences with a minimum value of zero and a maximum value of 36 sentences. The results also show that CEOChairperson separation, audit committee effectiveness, state ownership, firm complexity, size and profitability positively affect risk disclosure. However, we find no significant correlations for board independence, institutional ownership, auditor type, leverage, and firm age.

Originality/value: This study is important because it fills gaps in the disclosure literature, especially in developing and Arab countries, and responds to calls in previous studies, such as Dobler et al. (2011), Ntim et al. (2013), and Moumen et al. (2015), that recommend investigating the corporate governance determinants of risk disclosure in these contexts. The results are of interest to accounting setters and governance regulators. The study also provides an evaluation of the Saudi governance code formally applied in 2007.
\end{abstract}

Keywords: Risk Disclosure; Corporate Governance; Ownership Structure; Content Analysis; Saudi Arabia 


\section{Introduction}

Risk Disclosure (RD) is the dissemination of any quantitative or qualitative information about uncertainties or risks facing the firm (Linsley \& Shrives, 2006; Elbannan \& Elbannan, 2015). Examples of these risks include financial risks such as interest rates, exchange rates and liquidity risks; operational risks such as customer dissatisfaction or product or service failure; integrity risks such as illegal acts and earnings management; and strategic risks such as competitors and industry-related risks (ICAEW, 1997; Linsley \& Shrives, 2006).

$\mathrm{RD}$ is one of the most important disclosure types for a number of reasons. First, RD conveys the present and potential risks facing firms during the course of business. Second, RD could have important investment, financing, and liquidity implications by reducing agency and information asymmetry problems (Abraham \& Cox, 2007; Ntim et al., 2013). Third, the Institute of Charted Accountants in England \& Wales (ICAEW, 1997) underlines that RD could lead to improvements in accountability for stewardship, investor protection, and the usefulness of financial reporting, and better risk management. Consequently, we believe that RD could be one of the most value-relevant disclosures.

However, although several Corporate Governance (CG) codes and developed countries, such as the USA, the UK, and Germany mandate certain kinds of risk information disclosure, a large portion of risk information is still offered on a voluntary basis (Elshandidy et al., 2015; Moumen et al., 2015). This is reflected in the large variations of quantity and quality of RD found between firms and across countries, as highlighted by a number of studies. For example, Linsley and Shrives (2006) find that the mean RD is 78 sentences in a sample of UK firms, ranging from 20 sentences to 275 sentences. In contrast, Elzahar and Hussainey (2012) document that the mean RD is 20 sentences in a sample of UK firms, ranging from five sentences to 110 sentences. Moreover, Elshandidy et al. (2015) find significant variations in mandatory and voluntary RD across Germany, the UK and the USA.

Accordingly, a key question is raised: what drives certain firms to disclose greater levels of risk information while others disclose lower levels or none? The literature addresses this question by investigating various RD determinants, such as CG, ownership structure and corporate characteristics (e.g. Linsley \& Shrives, 2006; Abraham \& Cox, 2007; Hassan, 2009; Elzahar \& Hussainey, 2012; Ntim et al., 2013; El-Shammari, 2014).

However, the literature still suffers from a shortage of studies that investigate CG determinants of RD, especially in developing and Arab countries. This is highlighted in recent studies, such as Ntim et al. (2013), Mokhtar and Mellett (2013) and Moumen et al. (2015), who all argue that there are a limited number of studies dealing with effect of governance attributes on RD quality and recommend examining this issue in future research. Accordingly, this study contributes by responding to these calls by investigating the influence of CG, ownership structure and certain corporate characteristics on RD level in a developing Arab country, Saudi Arabia, in which there is a lack of research in this area.

The Saudi Arabian market is important to investigate for the following reasons. First, in November 2016, the total firms listed in Saudi Market reached 178 firms with a market capitalization of approximately $\$ 550 \mathrm{bn}$, which equals roughly half of total Arab Stock Market Capitalization (www.tadawul.com.sa). This makes the Saudi market one of the most important developing economies to examine how governance could influence financial reporting. Second, Saudi formal rules are strictly based on Islamic principles (Hussainey \& Al-Nodel, 2008; AlMatari et al., 2012), which affect the Saudi governance system and create Islamic governance characteristics (Albassam, 2014). Third, corporate ownership in Saudi Arabia is family- or state-concentrated. Family-owned firms account for more than $70 \%$ of the listed firms, while Saudi government accounts for around 30\% of the listed firms (Baydoun et al., 2013; Albassam, 2014). Fourth, Saudi Arabia is an important member of OPEC, has about $25 \%$ of the world's 
oil reserves and is one of the largest oil producers in OPEC (Albassam, 2014). Finally, the Saudi market suffers a clear paucity in RD studies. This has motivated us to investigate the determinants of RD quantity in a different context: the Arab and emerging market context.

The results show that the average RD is 13 sentences with a minimum of zero and a maximum of 36 sentences. This indicates that the level of RD in Saudi Arabia is moderate, compared with averages of 78 and 28 in the UK, and 20 in Kuwait found by Linsley and Shrives (2006), Elzahar and Hussainey (2012), and Al-Shammari (2014), respectively. The regression analysis highlights that CEO-Chairperson separation, audit committee effectiveness, state ownership, firm complexity, size and profitability positively affect RD level, while we find no significant correlations for board independence, institutional ownership, auditor type, leverage, and firm age.

The remainder of this study is organized as follows. Section two exhibits a background on RD standards and regulations in general and includes a sub-section about Disclosure regulations in Saudi Arabia. Section three reviews the relevant literature. Section four develops the study hypotheses, while Section five presents the study methodology. Section six exhibits the analysis results, discussion, and implications, while section six concludes.

\section{Risk Disclosure Standards \& Regulations}

Since the financial scandals and economic crises occurred during the last decades, RD has been the concern of accounting and professional bodies such as Financial Accounting Standard Board (FASB), German Accounting Standard Board (GASB), and Institute of Chartered Accountants in England and Wales (ICAEW). These bodies acknowledge the importance of $\mathrm{RD}$ and issue formal accounting standards, guidelines and frameworks encouraging and organizing RD. Accounting standards and regulations were issued to organize the process of financial reporting on risks facing firms in both non-financial industries and in the banking industry. The USA, UK, Germany and Canada are the first countries that issue specialized regulations regarding RD (Dobler et al. 2011; Elshandidy et al.2013). First, in January 1997, the Securities and Exchange Commission (SEC) in the USA issued Financial Reporting Release (FRR No.48), which obligates firms to disclose information on market risks associated with their activities. Afterward, in December 2005, the SEC expanded the FRR No. 48 scope to include disclosure on most significant risks factors facing firms. The 2005 SEC updates are considered a development of $\mathrm{RD}$ in the USA that requires companies to provide a comprehensive disclosure on risk factors, despite its qualitative nature. Moreover, Sections 302 and 404 of SOX in the USA require companies to evaluate and disclose on the effectiveness of internal control systems over financial reporting, which is considered a kind or RD. Second, in Germany in 2001, the GASB issued German Accounting Standard 5 (GAS-5) - "Risk Reporting", which obligates listed firms to provide information about different risks they face. To date, GAS-5 is considered the only comprehensive accounting standard on disclosure of different risks facing business; however, it is applied only in Germany. Third, ISA 32 and IFRS 7 are concerned with disclosure on financial instruments including risks associated with investments in these instruments. Fourth, in the banking industry, Basel Committee devoted Pillar 3 of Basel 2 Accord "Market Discipline" to organize RD in banks. Pillar 3 of Basel 2 Accord is an international issuance that is concerned with different risks that banks face; it was introduced in 2004, and subsequently revised in 2009 and 2015. Moreover, the guidelines of BCBS 239 were introduced in January 2013 by Basel Committee in order to help banks assess and disclose risks. Those guidelines are not mandatory to apply, but just to help managers assess, manage and disclose risks. Accordingly, there is no an international accounting standard that is concerned with the disclosure of all different types of risks similar to GAS 5 till now. 
Despite the fact that IFRS 7 and ISA 32 are international standards; their scope covers the disclosure of only financial instruments risks, even after the amendments to IFRS 7 in 2011, the focus of this standard is still on disclosure of financial instruments risks, although companies face financial and non-financial risks.

\section{1 Disclosure Regulations in Saudi Arabia}

The Saudi authorities show more attention to the disclosure issues since 1985, where the standard of "Disclosure and Transparency" was issued. Recently, the Saudi Arabia Capital Market Authority (CMA) formally issued the code of Corporate Governance in November 2006, and amended subsequently in 2010. The third part of this code is entitled "Disclosure and transparency", which shows policies and procedures related to disclosure and the disclosure in the board of directors' report. This part encourages managers to disclose information, such as classifications of board directors, compensations paid to board directors of board, and names of other firms that any board member is one of their boards' directors. Furthermore, the Saudi ministry of commerce in 1994 issued a resolution that mandates all public firms to establish audit committee with specific traits, such as size, expertise, and independence, which is responsible for ensuring the integrity of financial reporting. Afterward, the 2006 Saudi Governance Code maintains the same requirement of firms to establish an audit committee responsible for the integrity of financial reporting.

Recently, the Saudi Organization for Certified Public Accountants (SOCPA) has approved an IFRS transition plan, thereby, listed firms will prepare their financial statements according to IFRS for financial periods starting at a January 2017, which means that IFRS 7 is not applied in Saudi Arabia regarding disclosure on financial instruments. For banks and insurance companies, the Saudi Arabia Monetary Authority (SAMA), requires banks and insurance companies to report under IFRS standards (www.ifrs.org).

\section{Literature Review}

Compared to other disclosure types, the RD literature experiences a shortage in studies that examine the governance determinants of RD, particularly in developing countries (Ntim et al. (2013; Mokhtar and Mellett 2013; Moumen et al. 2015). This section reviews the most relevant studies that examine the determinants of $\mathrm{RD}$, in particular the $\mathrm{CG}$ determinants. First, for board independence, Abraham \& Cox (2007) and Probohudono et al. (2013) find a positive significant relation between the independent directors on boards and the RD level. Oliveria et al. (2011) find a positive significant relation between the independent directors on boards and the existence of a big-4 auditor and the RD level in Portugal. Ntim et al. (2013) find that board diversity, board size, independent directors on the board improve the RD level in South Africa. Elshandidy et al. (2013) find that firms with boards with higher board independence and effective audit environments provide higher aggregated RD level in the UK. Elshandidy \& Neri (2015) find that independent directors on boards improve voluntary RD level in the UK and improve mandatory RD level in Italy. However, Elzahar \& Hussainey (2012) and Al-Shammari (2014) find insignificant relationship between board independence and RD level. Second, board size is one of the governance determinants that literature provides two conflicting points of view about its effect. Ntim et al. (2013) in South Africa, Mokhtar \& Mellett (2013) in Egypt, Al-Shammari (2014) in Kuwait, and Elshandidy \& Neri (2015) in the UK and Italy find that board size is a positive governance determinant of RD. However, Elzahar \& Hussainey (2012) in the UK and Allini et al. (2016) in Italy find no significant relation. Third, whether the firm is audited by a big- 4 auditor or not is examined as a governance mechanism that may ensure 
financial reporting quality. Oliveria et al. (2011) in Portugal and Mokhtar \& Mellett (2013) in Egypt find that the auditor type is a positive significant driver of $\mathrm{RD}$, which is consistent with agency theory arguments. Fourth, effective audit committee is another positive governance determinant. However, Oliveria et al. (2011) in Portugal, Al-Shammari (2014) in Kuwait, and Allini et al. (2016) in Italy find no significant role for audit committee in improving RD.

Furthermore, Ntim et al. (2013) examine the influence of internal CG mechanisms on the quality and extent of RD in a sample of 169 firms listed on the Johannesburg Stock Exchange, South Africa, from 2002 to 2011. They find that RD contents are largely non-financial, are historical, feature good news and are qualitative in nature. The findings also indicate that block ownership and institutional ownerships are negatively correlated with the RD level, but board diversity, board size, and independent non-executive directors are positively correlated. In addition, Barakat and Hussainey (2013) examine the direct and joint effects of bank governance, regulations, and supervision on RD quality in a sample of 85 European banks during 2008-2010. They find that banks with a higher ratio of outside board directors, lower executive ownership, and a more active audit committee, and operating under regulations promoting bank competition provide high-quality RD. Consequently, the authors recommend ensuring board independence, enhancing audit committee activity, easing entry-to-banking requirements, and promoting a more proactive role for bank supervisors. Mokhtar and Mellett (2013) examine the extent and governance determinants of mandatory and voluntary RD by investigating a sample of 105 Egyptian-listed firms during 2007. They find a low level of compliance with mandatory risk reporting requirements ( $21.57 \%$ compliance level), and a low level of voluntary risk reporting (on average, 26 risk-related sentences with a range of 4 to 95). They also find that competition, role duality, board size, ownership concentration and auditor type are main determinants of risk reporting practices in Egypt. A recent study by Elshandidy and Neri (2015) examines the influence of CG on RD practices in the UK and Italy. The results indicate that governance factors influence the decisions of UK firms to disclose risk information voluntarily, whereas governance factors influence the decisions of Italian firms to disclose risk information mandatorily. The results also indicate that strongly governed firms in the UK are more likely to provide more meaningful risk information; however, in Italy strongly governed firms providing risk information voluntarily improves their market liquidity significantly.

On the other hand, corporate characteristics could be determinants of quality of financial reporting. First, agency theory assumes that larger firms are more likely to provide more information, since they face big agency and information asymmetry problems than smaller firms (Watts \& Zimmerman, 1983). In addition, the larger firms are expected to have resources and experience to provide high-quality disclosure than smaller firms. a large number of studies are found to provide empirical evidence on the positive significant relationship between firm size and RD, such as Linsley \& Shrives (2005), Linsley \& Shrives (2006), Iatridis (2008), Elzahar \& Hussainey (2012), and Elshandidy et al. (2013) in UK samples, Probohudono et al. (2013), Amran et al. (2009) in Malaysia, Taylor et al. (2010) in Australia, and Allini et al. (2016) in Italy. However, Hassan (2009) finds an insignificant relationship in UAE and Rajab \& Handley-Schachler (2009) in the UK. Second, the ratio of debt may be another determinant of RD. According to the agency theory, the highly leveraged firms may experience higher agency costs arising mainly from creditors and that additional disclosure may mitigate these costs (Jensen \& Meckling, 1976). Accordingly, leverage is expected to be a positive determinant of RD. However, Iatridis (2008) in the UK, Taylor et al. (2010) in Australia, Oliveira et al. (2011) in Portugal find a positive significant relationship between firm leverage and RD, while Linsley \& Shrives (2005) and Rajab \& Handley-Schachler (2009) in the UK, Tsamenyi et al. (2007) in Ghana, and Allini et al. (2016) in Italy find no relationship. Third, risk level may be a corporate determinant of RD level. Elshandidy et al. (2013) examine the influence of risk levels on RD in the UK. They hypothesize that the highly risky firms are more 
likely to disclose more risk information. They find that firms characterized by higher levels of different types of risks are positively associated with higher levels of aggregated and voluntary RD. Further, Hassan (2009) in UAE and Elshandidy et al. (2013) in the UK find a positive influence of risk level on RD level. However, Linsley \& Shrives (2005) in the UK find no influence of risk level on RD level.

To conclude, we notice a clear paucity of studies that examine the CG influence on RD level and quality and the few existing studies are undertaken in a limited number of developed countries: the UK, the USA, and Germany. Furthermore, we notice that most studies investigate RD quantity, which may not be expressive of the disclosure quality. Moreover, most study periods comprise only one year or a small number of years, which maybe because the content analysis is a labor-intensive technique.

\section{Hypotheses Development}

\section{Board Independence}

Boards are considered to be more independent when they are dominated by outside nonexecutive directors. Independence is more likely to provide more effective monitoring and governance (Fama \& Jensen, 1983), which could affect positively the accounting reporting quality (Elzahar \& Hussainey, 2012). According to agency theory, the independent boards could resolve the agency and information asymmetry problems through greater disclosure (Amran et al., 2009; Elzahar \& Hussainey, 2012), while the executive (dependent) directors have insufficient incentives regarding any type of disclosure including RD (Abraham \& Cox, 2007). According to stakeholders' theory, the presence of independent directors on boards is an importance CG mechanism that serves the needs of different stakeholders, especially the need for greater disclosure (Ntim et al. 2013). Empirically, a number of studies have found positive correlations between independent boards and RD quality (e.g. Abraham \& Cox, 2007; Ntim et al., 2013; Barakat \& Hussainey, 2013), while others found no significant correlation (e.g. Elzahar \& Hussainey, 2012). Based on the agency theory view of the positive role of independent boards in improving the disclosure quality, we hypothesize that:

\section{H1: There is a positive correlation between the boards' independence and the RD level.}

\section{Role Duality}

Role duality occurs when the Chief Executive Officer (CEO) is simultaneously the Chairperson. The Chairperson is responsible for controlling and managing the board (control function), while CEO is responsible for the day-to-day management (management function) of the firm (Ntim et al., 2013). Combining the two functions could reduce board effectiveness as a governance mechanism. Agency theory supports the separation of management and control functions and argues that separating the two positions could enhance board accountability and independence (Barako et al., 2006), and could positively affect the disclosure quality (Abdel-Fattah, 2008; Al-Janadi et al., 2013). Moreover, the resources-dependence and stakeholders' theories suggest that separation of board Chairperson and CEO positions positively affect the corporate performance and disclosure quantity and quality (Jensen, 1993; Barako et al., 2006; Ntim et al., 2013). Empirically, Mokhtar and Mellett (2013) found a negative significant correlation between role duality and mandatory risk reporting, while others have found no correlation (e.g. Elzahar \& Hussainey, 2012; Ntim et al., 2013). Consistent with agency theory and stakeholders' theory that imply that role duality could harm disclosure quality, we hypothesize that: 
H2: There is a positive correlation between the CEO-Chairperson separation and RD level.

\section{Audit Committee Effectiveness}

The audit committee is one of the main pillars of any CG system that is related to the board. This committee could play an effective monitoring and controlling role, and could ensure the integrity of financial reporting (Fama, 1980; Fama \& Jensen, 1983; Barakat \& Hussainey, 2013). However, the effectiveness of this committee depends on its structure and characteristics. According to Section 14 of the 2006 Saudi CG code, each firm should establish an audit committee of at least three non-executive directors, with at least one director specialized in financial and accounting affairs. As with several other CG codes, the Saudi code focuses on the number, independence, and expertise of audit committee members. However, empirically, Elzahar and Hussainey (2012) found no significant correlation between audit committee size and RD quality, whereas Xie et al. (2003) and Soliman and Ragab (2014) found that audit committees with a high number of experts improve the reporting quality. Furthermore, Barakat and Hussainey (2013) found a positive correlation between audit committee activity and RD level. Accordingly, we believe that effective audit committees consisting of at least three fully independent members, one of whom is an expert and that they hold at least three meetings a year, will improve the disclosure in general and RD in particular. Therefore, we hypothesize that:

H3: There is a positive significant correlation between audit committee effectiveness and RD level.

\section{State Ownership}

Governments could play a vital role in improving the disclosure quality through their shareholding in firms. Governments, as owners, are able to promote and apply good governance rules including those related to transparency and disclosure (Eng \& Mak, 2003; AbuRaya, 2012; Ntim et al., 2013). Furthermore, Eng and Mak (2003) argue that governments believe that CG and disclosure are necessary tools to protect shareholders. Consistent with the social role that governments play in order to protect their citizens from any threats, we believe that governments, as large investors, are able to protect other investors through improving the disclosure quality on risks and threats that face the firms. Empirically, Ntim et al. (2013) find a positive correlation between state ownership and RD quality. The authors explain that firms with high state ownership commit to high levels of RD in order to signal their congruence with government values, norms and rules, such as governance and transparency rules. Accordingly, we believe that governments could play a positive role in enhancing the RD quality through their ownership in firms, based on their role of protecting citizens in general and investors in particular. Therefore, we hypothesize that:

\section{H4: There is a positive significant correlation between state ownership and RD level.}

\section{Institutional Ownership}

The literature highlights two conflicting impacts of institutional investors on disclosure. The passive hands-off view assumes that institutional investors are passive and short-term investors are only concerned about their own interests (Al-Fayoumi et al., 2010), which implies that their 
existence may not affect levels of disclosure. In contrast, the efficient-monitoring view assumes that institutional investors are sophisticated and have experience and resources that enable effective monitoring of managers' decisions including disclosure-related decisions (AbdelFattah, 2008; Al-Fayoumi et al., 2010, AbuRaya, 2012). Furthermore, according to agency theory, institutional shareholders have extra incentives to closely monitor the disclosure practices (Abraham \& Cox, 2007; Elzahar \& Hussainey, 2012; Ntim et al., 2013). Regarding RD empirical evidence relating to RD, a number of studies find a negative correlation between institutional ownership and RD quality (e.g. Abraham \& Cox, 2007; Ntim et al., 2013), while others find no correlation (e.g. Elzahar \& Hussainey, 2012). Based on these competing views of role of institutional investors, we hypothesize:

\section{H5: There is a significant correlation between institutional ownership and RD level.}

\section{Auditor Type}

Audit firms around the world are classified into 'big' auditors and 'non-big' auditors. According to agency theory, the big audit firms are more likely to provide the highest quality auditing and assurance services (Mokhtar \& Mellett, 2013), which will result in high disclosure quality (Abdel-Fattah, 2008). The literature addresses the external auditor type as a governance mechanism that could affect the disclosure level. For example, Abd-Elsalam (1999) argues that big audit firms force their clients to adopt the accounting standards, ask them to follow the mandatory disclosure rules, and encourage them to disclose more information voluntarily. Empirically, Lopes and Rodrigues (2007) and Al-Shammari (2014) find a positive correlation between auditor type and RD level, while Mokhtar and Mellett (2013) find a positive correlation between auditor type and mandatory RD, but a negative correlation between auditor type and voluntary RD. Accordingly, we hypothesize that when a firm hires a big auditor, this is a signal of the good intention of the management. Furthermore, we concur with agency theory that big audit firms will provide high-quality audit assurance and thus high-quality disclosure. Based on this, we hypothesize:

H6: There is a positive significant correlation between auditor type and RD level.

\section{Corporate Characteristics}

First, for firm complexity, firms with complex structures and operations are more likely to suffer from higher information asymmetry, which places pressure on managers to provide more information. Al-Shammari (2014) finds that firms with greater complexity disclose more risk information. In the case firm leverage, managers of highly leveraged firms provide more risk information in order to send a signal (signaling theory) to creditors that they are able to pay their debts whenever they fall due (Elzahar \& Hussainey, 2012), and to mitigate the high agency costs (agency theory) that arise in highly leveraged firms (Jensen \& Meckling, 1976). In relation to firm size, agency theory argues that larger firms face higher agency costs arising from greater information asymmetry, which encourages them to disclose more information (Watts \& Zimmerman, 1983). Furthermore, we argue that larger firms are under greater pressure from a large number of their stakeholders (stakeholders' theory) to disclose more information, and that these firms have sufficient resources to do so. In addition, according to signaling theory, managers of large and complex firms disclose more information in order to signal the real value of these large firms (Ross, 1977; Abdel-Fattah, 2008). For firm age, we agree with Hossain (2008) that it is not possible to conclude that older firms disclose more information than do newer firms. Finally, in the case of firm profitability, agency theory argues that firms with high 
profitability tend to disclose more information in order to justify their present performance to shareholders (Elzahar \& Hussainey, 2012), and to justify their level of compensation.

\section{Methodology}

\section{Sample and Data}

The study population consists of all firms listed on the Saudi Stock Exchange. However, the final sample is restricted to 408 annual reports of 408 firm-year observations during the period 2012-2015. Table 1 shows that the total initial sample involves 656 firm-year observations, which are reduced by 158 observations that relate to financial, banking and insurance firms, and by a further 90 observations, due to a lack of data. The annual reports of the sample firms represent the study's main data source. We collected these annual reports from the firms' websites and from the website www.tadawual.com.sa.

\section{Insert Table 1 about here}

\section{Regression Model}

To test the study hypotheses, we estimate the following Ordinary Least Square (OLS) multiple regression model as:

$$
\begin{aligned}
\mathrm{RD}_{\mathrm{it}}= & \beta 0+\beta 1 \text { Brdind }_{i t}+\beta 2 \text { Dual }_{i t}+\beta 3 \text { ACscore }_{i t}+\beta 4 \text { statown }_{i t}+\beta 5 \text { Instown }_{i t}+\beta 6 \text { Big4 }_{i t} \\
& +\beta 7 \text { Complex }_{i t}+\beta 8 \text { Levrg }_{i t}+\beta 9 \text { Size }_{i t}+\beta 10 \text { Age }_{i t}+\beta 11 \text { ROA }_{i t}+\varepsilon
\end{aligned}
$$

\section{Dependent Variable}

To measure the model dependent variable (RD), we analyze the annual reports by using manual content analysis and then counting the number of the risk-related sentences. Word, sentence, paragraph or even page are used in disclosure literature as measurement units of disclosure. Our choice of a sentence as a measurement unit is because words may not indicate any meaning if not used inside a complete sentence. Moreover, the sentence as a coding unit could help avoid the double-counting problem as well (Elshandidy \& Neri, 2015). Using a measurement unit larger than a sentence such as a paragraph could include information far from risk information context. To define the risk and determine the risk-related sentences, we follow Linsley and Shrives (2006), Abraham and Cox (2007), and Elzahar and Hussainey (2012) by considering any sentence a risk-related sentence, if it informs the reader of any opportunity or prospect, or any hazard, danger, harm, threat, or exposure that has influenced or may influence the firm in the future, or the management of any of these cases. The final score of RD represents the number of risk-related sentences stated in the annual report of each year-observation. We use the risks categorization presented by Linsley and Shrives (2006) as a guide in defining the risks in annual reports (see Appendix A).

We adopt the definition of risk as a two-side one that covers gain or loss. IFRS 7 considers disclosure on risks as gains or losses. Moreover, Linsley \& Shrives (2006), Abraham \& Cox (2007), Elshandidy et al. (2013; 2015) and Elshandidy \& Neri (2015) all adopt the two-side definition of risk. Therefore, the study list of risk words includes both opportunity and loss. On the other hand, if any sentence is too fuzzy to understand and whether it is describing the risk- 
related issue or not, it is excluded and sentences should be recorded once if repeat the same meaning.

The content analysis gained a greater validity and wide fame in the disclosure studies (e.g. Linsley and Shrives, 2006; Abraham and Cox, 2007; Abdel-Fattah, 2008; Kothari et al. 2009; Elzahar and Hussainey, 2012). Moreover, the content analysis ensures the repeatability and valid references from data (Krippendorff, 2013). The content analysis enables independent evaluation of the annual reports' information away from its providers. Accordingly, we measure RD quantity following prior research using the manual content analysis (e.g. Li, 2008; Moumen et al., 2015). The manual rather than computerized content analysis is used to measure RD. First, the examined annual reports are written in the Arabic language, which needs advanced programming software to conduct the computerized content analysis. Furthermore, the vast majority of annual reports are found to be scanned PDF files, which needs to convert from scanned to editable PDF files, and then to convert into TEXT files and then to handle with any of advanced content analysis software. Accordingly, we decide to conduct the manual content analysis to ensure accuracy and avoid any unintentional mistakes throughout these several steps. Since the manual content analysis may be subjective; therefore, two of the three authors examined each annual report and coded the risk-related sentences independently, and we found no significant differences for the RD score. Moreover, following Elzahar and Hussainey (2012), we ignored any risk-related sentence that is ambiguous.

\section{Independent Variables}

We examine two sets of independent variables. The first consists of six CG variables: board independence, role duality, audit committee effectiveness, state ownership, institutional ownership, and auditor type. Regarding the audit committee, we construct an aggregate score to measure its effectiveness, similar to Brown and Caylor (2006) and Jiang et al. (2008), and based on the characteristics recommended by the 2006 Saudi CG code. The second consists of five corporate characteristics: firm complexity, leverage, size, age, and profitability. Table 2 displays the definitions and measurements of all the study variables.

\section{Insert Table (2) about here}

\section{Results}

\section{Descriptive Statistics}

Table 3 highlights the descriptive statistics. First, the mean value of the RD variable is 12.59 with a minimum value of zero and a maximum value of 36 , indicating that the annual reports, on average, include 13 risk-related sentences, and that there are some reports without any riskrelated sentences, while others include up to 36 sentences as a maximum. The average is very low compared with averages of 78, 28, and 20 sentences found by Linsley and Shrives (2006), Elzahar and Hussainey (2012), and Al-Shammari (2014), respectively. In addition, the disclosure score found by Tsamenyi et al. (2007) in Ghana as a developing country is $48.23 \%$. Second, the mean of the Brdindp variable is 0.58 , indicating that $58 \%$ on average of the directors on the sample boards are independent. This is lower than the average of $68.14 \%$ found by Elzahar and Hussainey (2012) for a UK sample, but higher than average of $47.12 \%$ found by Ntim et al. (2013) for a South African sample. Third, the mean of the Dual variable is 0.89 , indicating that $89 \%$, on average, of sample boards' CEOs do not serve as Chairpersons at the 
same time. However, this mean is lower than $98.95 \%$ found by Ntim et al. (2013) for a South African sample. Fourth, the mean value of ACscore variable is 1.14, implying that less than half of the sample audit committees, are effective. Fifth, the mean value of Statown variable is 0.13 , which indicates that only $13 \%$ of the sample's outstanding shares are owned by Saudi governmental agencies, while the mean of Instown variable is 0.13 , indicating that only $13 \%$ of the sample's outstanding shares are owned by institutional investors, on average. Sixth, the mean value of Big4 variable is 0.68, which indicates that a big-4 auditor audits $68 \%$ of the sample firms, on average. Finally, the descriptive statistics of corporate characteristics show a wide variability, which reduces the bias possibility in our sample selection (Ntim et al., 2013).

\section{Insert Table 3 about here}

\section{Pearson Correlation Test}

Table 4 shows the results of the Pearson correlation test. This test helps diagnose if there is any multi-collinearity between the independent variables. The table shows that the Dual, ACscore, Statown, Instown, Big4, Complex, Levg, Size, Age, and ROA variables are statistically significant at $5 \%$ and positively correlated with the RD variable. While the highest correlation coefficients between the independent variables are -0.52 at $1 \%$ between Brdindep and ACscore variables, followed by 0.46 at $1 \%$ between ACscore and Complex variables. These correlations do not represent a serious multi-collinearity problem, since they do not exceed $50 \%$. In this regard, Bryman and Cramer (2001), Gujarati (2003), and Mokhtar and Mellett (2013) argue that the correlations between independent variables represent a serious multi-collinearity problem only if they exceed $80 \%$.

\section{Insert Table 4 about here}

\section{Regression Results}

We estimate the study model using OLS regression analysis. Table 5 summarizes the regression results. First, the results show that independent variables explain $62 \%$ of the variations of the $\mathrm{RD}$ level, where adjusted $\mathrm{R}^{2}=0.62$. This is higher than the $26 \%$ found by Elzahar and Hussainey (2012) for a UK sample. Moreover, the overall model is statistically significant, where the F-value $=61.28$ and $\mathrm{Prob}>\mathrm{F}=0.000$.

In relation to the CG variables, the results show that only Dual, ACscore, and Statown are determinants of the RD level. First, the coefficient of Brdindp variable is positive, but statistically insignificant $(\beta 1=0.72, \mathrm{t}$-statistic $=0.50)$, indicating that the board independence may not be a determinant of RD level. This result is consistent with that of Elzahar and Hussainey (2012) and Al-Shammari (2014). However, it is inconsistent with that found by majority of related studies such as Abraham \& Cox (2007) in the UK, Oliveria et al. (2011), Ntim et al. (2013) in South Africa, Elshandidy et al. (2013) in the UK, Probohudono et al. (2013), and Elshandidy \& Neri (2015) who find a positive significant relation between the independent directors on boards and the RD level. Moreover, the result does not support the agency theory argument that board independence could increase the disclosure in order to resolve the agency and information asymmetry problems (Eng \& Mak, 2003; Amran et al., 2009; Abraham \& Cox, 2007; Ntim et al., 2013). It also contradicts the arguments of stakeholders' theory that presence of independent directors on boards could be deemed an important CG structure which serves the interests of other stakeholders in promoting greater disclosure (Ntim et al., 2013). Accordingly, we reject the study's first hypothesis. 
Second, the coefficient of CEO-Chairperson separation (Dual Variable) is positive and statistically significant at $1 \%(\beta 2=2.78, \mathrm{t}$-statistic $=3.31)$, implying that the independence of the board Chairperson increases the RD level. This result confirms the suggestions of agency, resources-dependence and stakeholders' theories that separation of board Chairperson and CEO positions could affect positively the corporate performance and disclosure (Jensen, 1993; Barako et al., 2006; Tsamenyi et al. 2007; Ntim et al., 2013). This result agrees with that of Mokhtar and Mellett (2013) who found a negative significant correlation between role duality and mandatory RD. Accordingly, we accept the study's second hypothesis.

Third, the coefficient of ACscore variable is found to be positive and statistically significant $(\beta 3=3.03$, t-statistic $=4.18)$, indicating that audit committee effectiveness may be a positive determinant of the RD level. This result is consistent with Soliman and Ragab (2014) found a positive correlation between audit committee effectiveness and the disclosure quality and similarly Barakat and Hussainey (2013) found a positive correlation between audit committee activity and RD level. However, our result is inconsistent with that found by Oliveria et al. (2011) in Portugal, Al-Shammari (2014) in Kuwait, and Allini et al. (2016) in Italy, who find no significant role for audit committee in improving RD. Moreover, Elzahar and Hussainey (2012) found no significant correlation between audit committee size and RD quality. Accordingly, we accept the study's third hypothesis.

Fourth, the coefficient of Statown variable is found to be positive and statistically significant at $1 \%(\beta 4=2.62$, t-statistic $=3.28)$, indicating that state ownership could increase the RD level. This result confirms our arguments that governments, as large owners, could play a positive role in improving the RD level, based on their main role which is to protect the citizens in general and the investors in particular. The result agrees with that of Ntim et al. (2013) in the RD context and with Eng and Mak (2003) in the voluntary disclosure context. Accordingly, we accept the study's fourth hypothesis.

\section{Insert Table 5 about here}

Fifth, the coefficient of Instown variable found to be positive, but statistically insignificant $(\beta 5=1.60$, t-statistic $=1.04)$, implying that institutions as owners may not affect the RD level. This result is consistent with the passive hands-off view that hypothesizes that institutional investors are passive and will not affect the overall disclosure level (Al-Fayoumi et al., 2010). The result is also consistent with Elzahar and Hussainey (2012) who found no correlation between the two variables. However, the result does not support the agency theory suggestion that institutional investors have additional incentives to closely monitor the disclosure policies and practices, which may affect the RD positively (Abraham \& Cox, 2007; Elzahar \& Hussainey, 2012; Ntim et al., 2013). Accordingly, we reject the study's fifth hypothesis.

Sixth, the coefficient of Big4 variable is positive, but statistically insignificant ( $\beta 6=0.83, \mathrm{t}-$ statistic $=1.31$ ), which indicates that auditor type may not be a determinant of RD level. This result contradicts results of Lopes and Rodrigues (2007), Mokhtar and Mellett (2013), and AlShammari (2014) who found a significant correlation between auditor type and RD level. Moreover, the result does not support the argument of agency theory that firms audited by Big4 auditors disclose more information voluntarily (Abdel-Fattah, 2008; Mokhtar \& Mellett, 2013). Accordingly, we reject the study's sixth hypothesis.

In relation to the corporate characteristics variables, the analysis shows that all examined characteristics are statistically significant, except for firm leverage and firm age. First, the coefficient of ROA variable is positive and statistically significant $(\beta 11=6.55$, t-statistic $=1.96)$, indicating that firm profitability might be a determinant of the RD level, which is inconsistent with the result of Elzahar and Hussainey (2012). This result does support the arguments of the 
agency and political costs theories that profitability could affect the voluntary disclosure positively, since managers of these firms could make personal gains through additional disclosure, such as creating a good reputation and justifying the compensation package (Inchausti, 1997; Barako, 2007).

The coefficients of firm complexity and size are positive and statistically significant at $1 \%$ and 5\%, respectively, indicating that more complex and larger firms are more likely to disclose more risk information than other firms do. This result agrees with agency theory that larger and complex firms face higher information asymmetry and agency costs, which managers mitigate through providing more disclosure (Elzahar \& Hussainey, 2012). Furthermore, the results confirm the argument of stakeholders' theory that the various stakeholders in large firms encourage pressure to disclose more information voluntarily. The results of firm size are consistent with the argument of the stakeholders' theory that larger firms are followed by a larger number of stakeholder and managers should satisfy the information needs of all stakeholders. Moreover, the results agree with the signaling theory argument that managers of large and complex firms disclose more information to mitigate the large information asymmetry and to signal the real value of firms (Ross, 1977; Abdel-Fattah, 2008). Our result is consistent with Al-Shammari (2014) in Kuwait and Tsamenyi et al. (2007) in Ghana who finds a significant positive correlation between firm size and complexity and the RD level. However, Hassan (2009) finds insignificant relationship in UAE and Rajab \& Handley-Schachler (2009) in the UK

In addition, the firm leverage was found to be negative and statistically insignificant ( $\beta 8=-$ 0.55 , $\mathrm{t}$-statistic $=-0.26$ ), which indicates that leverage may not affect the disclosure levels. In this regard, the agency theory argues that highly leveraged firms disclose more information to mitigate the high agency costs they face because of high debts (Jensen \& Meckling, 1976). Moreover, the signaling theory argues that highly leveraged firms disclose more information to send a contentment signal to creditors that they can pay their debts whenever they fall due (Elzahar \& Hussainey, 2012). However, Iatridis (2008) in the UK, Taylor et al. (2010) in Australia, and Oliveira et al. (2011a) in Portugal find a positive significant relationship between firm leverage and RD, while Linsley \& Shrives (2005) and Rajab \& Handley-Schachler (2009) in the UK, Tsamenyi et al. (2007) in Ghana, and Allini et al. (2016) in Italy find no relationship.

To conclude, the regression results highlight that CEO-Chairperson separation, audit committee effectiveness, state ownership, firm complexity, size and profitability positively affect RD level, while we find no significant correlations for board independence, institutional ownership, auditor type, leverage, and firm age.

These results provide many implications for market participants. First, investors and analysts should recognize the low level of RD and demand greater RD from the managers. Furthermore, they should recognize also that larger and complex firms disclose more risk information than other firms do. Second, the Saudi government agencies, as owners, should recognize the positive role that they can play in improving the RD level through holding shares in listed firms. Third, the insignificant result on the role of institutional investors in improving RD should be considered and those investors should be asked by other owners to play a more significant role, instead of the passive hands-off role. Fourth, CG regulators should notice that the characteristics of the effective audit committee as described by the Saudi CG code might need improvements, since it is found to play a role in affecting the RD level, in contrast to state ownership which could play a positive role as a governance mechanism. However, the level of quantity and quality of RD in Saudi Arabia is more likely to improve after the adoption of IFRS in Saudi Arabia in 2017, as announced by COCPA, where RD-related standards such as IFRS 7 will be applied. 


\section{Conclusion}

The objective of this study is to determine the main CG and corporate characteristics determinants of RD level in an emerging country Saudi Arabia in which there is a lack of research in this area. We examine a sample of 408 annual reports of firms listed on the Saudi Exchange during 2012-2015. We use the sentence approach to determine the extent of RD in the sample annual reports, in addition to the content analysis and regression analysis.

The results reveal that the RD level in Saudi Arabia ranges from zero to a maximum of 36, with an average of 13 sentences. The regression results provide evidence that none- dual role, audit committee effectiveness, state ownership, firm complexity, size and profitability positively affect risk disclosure. However, we find no significant correlations for board independence, institutional ownership, auditor type, leverage, and firm age.

This study suffers from many limitations. First, because of the use of manual content analysis which is labor intensive, we only examine a small sample. Second, we apply manual content analysis, which may be more subjective than the computerized content analysis. Third, we focus on the quantity rather than the qualitative characteristics of risk statements.

Finally, we provide a number of recommendations for further research. First, we recommend investigating the $\mathrm{CG}$ determinants of $\mathrm{RD}$ in a larger range by widening the sample size, the study years and adding further determinants, and conducting a cross-country study that comprises developing and developed markets. Second, we recommend investigating the RD quality rather than quantity by measuring its qualitative characteristics. Third, further research is still required to investigate the economic consequences of RD quantity and quality, such as the influence of RD quality on the cost of capital/debt, information asymmetry, and firm value. Finally, it would be interesting to examine and compare RD practices in Saudi Arabia after the adoption of IFRS in 2017, and whether the quality of RD and value-relevance would be improved. 


\section{References}

Abdel-Fattah, T. M. H. 2008. Voluntary disclosure practices in emerging capital markets: the case of Egypt. PhD Thesis. Durham University. Available at: http://etheses.dur.ac.uk/1342/

Abd-Elsalam, O. 1999. The introduction and application of accounting standards to accounting disclosure regulation of a capital market in a developing country: the case of Egypt. PhD Thesis, Herriot-Watt University, Edinburgh, UK. Available at: http://www.ros.hw.ac.uk/handle/10399/1260

Abraham, S. and P. Cox. 2007. Analyzing the determinants of narrative risk information in UK FTSE 100 annual reports. The British Accounting Review 39 (3): 227-248.

AbuRaya, R. K. 2012. The relationship between corporate governance and environmental disclosure: The UK evidence. $\mathrm{PhD}$ Thesis, Durham University. Available at: http://etheses.dur.ac.uk/3456/

Albassam, W. M. 2014. Corporate governance, voluntary disclosure and financial performance: an empirical analysis of Saudi listed firms using mixed-methods of research design. PhD Thesis. University of Glasgow. Available at: http://theses.gla.ac.uk/5280/

Al-Fayoumi, N., B. Abuzayed and D. Alexander. 2010. Ownership structure and earnings management in emerging markets: the case of Jordan. International Research Journal of Finance and Economics 38 (1): 28-47.

Al-Janadi, Y., R. A. Rahman and N. H. Omar. 2013. Corporate governance mechanisms and voluntary disclosure in Saudi Arabia. Research Journal of Finance and Accounting 4 (4): 25-36.

Allini, A., Manes Rossi, F., Hussainey, K., 2016. The board's role in risk disclosure: an exploratory study of Italian listed state-owned enterprises. Public Money \& Management 36 (2): 113-120.

Al-Matari, A. K. Al-Swidi and B. Fadzil. 2012. Corporate governance and performance of Saudi Arabia listed companies. British Journal of Arts and Social Sciences 9 (1): 1-30.

Al-Shammari, B. 2014. Kuwait corporate characteristics and level of risk disclosure: a content analysis approach. Journal of Contemporary Issues in Business Research 3 (3): 128-153.

Amran, A., A. M. R. Bin and B. C. H. M. Hassan. 2009. Risk reporting: an exploratory study on risk management disclosure in Malaysian annual reports. Managerial Auditing Journal 24 (1): 39-57.

Barakat, A. and K. Hussainey. 2013. Bank governance, regulation, supervision, and risk reporting: evidence from operational risk disclosures in European banks. International Review of Financial Analysis 30 (December issue): 254-273.

Barako, D. G. 2007. Determinants of voluntary disclosure in Kenyan companies' annual reports. African Journal of Business Management 1 (5): 113-128. 
Barako, G., P. Hancock and Y. Izan. 2006. Factors influencing voluntary corporate disclosure by Kenyan companies. Corporate Governance: An International Review 14 (2): 107-125.

Baydoun, N., W. Maguire, N. Rayan and R. Willett. 2013. Corporate governance in five Arabian Gulf countries. Managerial Auditing Journal 28 (1): 7-22.

Brown, D. and L. Caylor. 2006. Corporate governance and firm valuation. Journal of Accounting and Public Policy 25 (4): 409-434.

Bryman, A. and D. Cramer. 2001. Quantitative data analysis with SPSS release 10 for windows: A guide for social scientists ( $1^{\text {st }}$ edition), United Kingdom, London, Routledge.

Dobler, M., K. Lajili and D. Zeghal. 2011. Attributes of corporate risk disclosure: an international investigation in the manufacturing sector. Journal of International Accounting Research 10 (2): 1-22.

Elbannan, M. A. and M. A. Elbannan. 2015. Economic consequences of bank disclosure in financial statements before and during the financial crisis: evidence from Egypt. Journal of Accounting, Auditing, and Finance 30 (2): 181-217.

Elshandidy, T., I. Fraser and K. Hussainey. 2013. Aggregated, voluntary, and mandatory risk disclosure incentives: evidence from UK FTSE all-share companies. International Review of Financial Analysis 30 (December issue): 320-333.

Elshandidy, T. M. F. 2011. Risk Reporting Incentive: A Cross-Country Study. PhD Dissertation. Stirling Management School, Stirling University, UK.

Elshandidy, T. M. F., I. Fraser and K. Hussainey. 2015. What drives mandatory and voluntary risk reporting variations across Germany, UK and US? The British Accounting Review 47 (4): 376-394.

Elshandidy, T. M. F. and L. Neri. 2015. Corporate governance, risk disclosure practices, and market liquidity: comparative evidence from the UK and Italy. Corporate Governance: An International Review 23 (4): 331-356.

Elzahar, H. and K. Hussainey. 2012. Determinants of narrative risk disclosures in UK interim reports. The Journal of Risk Finance 13 (2): 133-147.

Eng, L. and Y. Mak. 2003. Corporate governance and voluntary disclosure. Journal of Accounting and Public Policy 22 (4): 325-345.

Fama, E. 1980. Agency problems and the theory of the firms. Journal of Political Economy 88 (2): $288-307$.

Fama, E. and M. Jensen. 1983. Separation of ownership and control. Journal of Law and Economics 26 (2): 301-325.

Gujarati, D. 2003. Basic Econometrics, $4^{\text {th }}$ edition, McGraw-Hill, London, UK. 
Hassan, M. 2009. UAE corporations-specific characteristics and level of risk disclosure. Managerial Auditing Journal 24 (7): 668-687.

Hossain, M. 2008. The extent of disclosure in annual reports of banking companies: the case of India. European Journal of Scientific Research 23 (4): 659-680.

Hussainey, K. and A. Al-Nodel. 2008. Corporate governance online reporting by Saudi listed companies. Corporate Governance in Less Developed and Emerging Economies 8: 3964.

Iatridis, G., 2008. Accounting disclosure and firms' financial attributes: Evidence from the UK stock market. International Review of Financial Analysis 17, 219-241.

Inchausti, B. G. 1997. The influence of company characteristics and accounting regulation on information disclosed by Spanish firms. The European Accounting Review 6 (1): 45- 68.

Institute of Chartered Accountants in England and Wales. 1997. Financial Reporting of RiskProposals for a Statement of Business Risk, ICAEW, London.

Jensen, M. C. 1993. The modern industrial revolution, exist and the failure of internal control systems. Journal of Finance 48 (3): 831-880.

Jensen, M. and W. Meckling. 1976. Theory of the firm: managerial behavior, agency costs and ownership structure. Journal of Financial Economics 3 (4): 305-360.

Jiang, W., P. Lee and A. Anandarajan. 2008. The association between corporate governance and earnings quality: Further evidence using the GOV-Score. Advances in Accounting 24 (2): 191-201.

Kothari, S. P., X. Li and J. E. Short. 2009. The effect of disclosures by management, analysts, and business press on cost of capital, return volatility, and analyst forecasts: a study using content analysis: The Accounting Review 84 (5): 1639-1670.

Krippendorff. K. 2013. Content Analysis: An Introduction to its Methodology. Third Edition. Sage Publications, Inc. USA.

Li, F. 2008. Annual report readability, current earnings, and earnings persistence. Journal of Accounting and Economics 45 (2-3): 221-247.

Linsley, P. M. and P. J. Shrives. 2006. Risk reporting: a study of risk disclosures in the annual reports of UK companies. The British Accounting Review 38 (4): 387-404.

Linsley, P.M., Shrives, P.J., 2005. Examining risk reporting in UK public companies. The Journal of Risk Finance 6, 292-305.

Lopes, P. T. and L. L. Rodrigues. 2007. Accounting for financial instruments: an analysis of the determinants of disclosure in the Portuguese Stock Exchange. International Journal of Accounting 42 (1): 25-56.

Mokhtar, E. S. and H. Mellett. 2013. Competition, corporate governance, ownership structure and risk reporting. Managerial Auditing Journal 28 (9): 838-865. 
Moumen, N., H. B. Othman and K. Hussainey. 2015. The value relevance of risk disclosure in annual reports: evidence from MENA emerging markets. Research in International Business and Finance 34 (May issue): 177-204.

Ntim, C. G., S. Lindop and D. A. Thomas. 2013. Corporate governance and risk reporting in South Africa: a study of corporate risk disclosures in the pre-and post-2007/2008 global financial crisis periods. International Review of Financial Analysis 30 (December issue): 363-383.

Oliveira, J., Rodrigues, L.L., Craig, R., 2011. Risk-related disclosures by non-finance companies. Managerial Auditing Journal 26 (9): 817-839.

Probohudono, A. N., Tower, G., Rusmin, R., 2013. Risk disclosure during the global financial crisis. Social Responsibility Journal 9 (1): 124-137.

Rajab, B., Schachler, M. H., 2009. Corporate risk disclosure by UK firms: trends and determinants. World Review of Entrepreneurship, Management and Sustainable Development 5 (3): 224.

Ross, S. 1977. The determination of financial structure: the incentives-signaling approach. Bell Journal of Economics 8 (1): 23-40.

Soliman, M. M. and A. A. Ragab. 2014. Audit committee effectiveness, audit quality and earnings management: an empirical study of the listed companies in Egypt. Research Journal of Finance and Accounting 5 (2): 155-166.

Taylor, G., Tower, G., Neilson, J., 2010. Corporate communication of financial risk. Accounting \& Finance 50, 417-446.

The Saudi Stock Exchange (Tadawul). 2015. (www.tadawul.com.sa).

Tsamenyi, M., Enninigful-Adu., and Onumah, J. 2007. Disclosure and corporate governance in developing countries: evidence from Ghana. Managerial Auditing Journal 22 (3): 319334.

Watts, R. L. and J. L. Zimmerman. 1983. Agency problems, auditing and the theory of the firm: some evidence. Journal of Law and Economics 26 (3): 613-633.

Xie, B., W. N. Davidson and P. J. DaDalt. 2003. Earnings management and corporate governance: the role of the board and the audit committee. Journal of Corporate Finance 9 (3): 295-316. 
Appendix A: Categories of Risks

\begin{tabular}{|c|c|}
\hline Financial risk & $\begin{array}{l}\text { Interest rate; } \\
\text { Exchange rate; } \\
\text { Commodity; } \\
\text { Liquidity; } \\
\text { Credit }\end{array}$ \\
\hline Operations risk & $\begin{array}{l}\text { Customer satisfaction; } \\
\text { Product development; } \\
\text { Efficiency and performance; } \\
\text { Sourcing; } \\
\text { Stock obsolescence and shrinkage; } \\
\text { Product and service failure; } \\
\text { Environmental; } \\
\text { Health and safety; } \\
\text { Brand name erosion }\end{array}$ \\
\hline Empowerment risk & $\begin{array}{l}\text { Leadership and management; } \\
\text { Outsourcing; } \\
\text { Performance incentives; } \\
\text { Change readiness; } \\
\text { Communications }\end{array}$ \\
\hline $\begin{array}{l}\text { Information processing and } \\
\text { technology risk }\end{array}$ & $\begin{array}{l}\text { Integrity; } \\
\text { Access; } \\
\text { Availability; } \\
\text { Infrastructure }\end{array}$ \\
\hline Integrity risk & $\begin{array}{l}\text { Management and employee fraud; } \\
\text { Illegal acts; } \\
\text { Reputation }\end{array}$ \\
\hline Strategic risk & $\begin{array}{l}\text { Environmental scan; } \\
\text { Industry; } \\
\text { Business portfolio; } \\
\text { Competitors; } \\
\text { Pricing; } \\
\text { Valuation; } \\
\text { Planning; } \\
\text { Life cycle; } \\
\text { Performance measurement; } \\
\text { Regulatory; } \\
\text { Sovereign and political }\end{array}$ \\
\hline
\end{tabular}

Source: Linsley and Shrives,( 2006). 
Table (1): The study sample firm-year observations

\begin{tabular}{lccccc}
\hline & $\mathbf{2 0 1 2}$ & $\mathbf{2 0 1 3}$ & $\mathbf{2 0 1 4}$ & $\mathbf{2 0 1 5}$ & Total \\
\hline Initial Sample & 159 & 161 & 167 & 169 & 656 \\
\hline Less: Financial, Banking, and Insurance firm-year & $(39)$ & $(39)$ & $(40)$ & $(40)$ & $(158)$ \\
\hline Less: Firm-year observations with missing data & $(24)$ & $(21)$ & $(21)$ & $(24)$ & $(90)$ \\
\hline Final Sample & 96 & 101 & 106 & 105 & 408 \\
\hline
\end{tabular}

Table 2: The Variables' Definitions and Measurements

\begin{tabular}{ccc}
\hline Symbol & Definition & \multicolumn{1}{c}{ Measurement } \\
\hline Dependent Variable & \\
\hline RD it & $\begin{array}{c}\text { Risk Disclosure } \\
\text { Score }\end{array}$ & $\begin{array}{l}\text { The number of risk-related sentences (sentences that informs the reader of any } \\
\text { opportunity or prospect, or any hazard, danger, harm, threat, or exposure that has } \\
\text { influenced or may influence the firm in the future, or the management of any of these } \\
\text { cases (Linsley \& Shrives, 2006; Elzahar \& Hussainey, 2012). }\end{array}$
\end{tabular}

\section{Corporate Governance Variables}

\begin{tabular}{|c|c|c|}
\hline Brdindp it & $\begin{array}{l}\text { Board } \\
\text { Independence }\end{array}$ & $\begin{array}{l}\text { The ratio of outside directors to total number of directors on the board for the firm } \mathrm{i} \\
\text { during the year } \mathrm{t} \text {. }\end{array}$ \\
\hline Dual it & Role Duality & $\begin{array}{l}\text { This variable is a dummy variable that equals one if the CEO of the firm } \mathrm{i} \text { and the } \\
\text { year } \mathrm{t} \text {, does not serve as a board Chairperson, and zero otherwise. }\end{array}$ \\
\hline ACscore it & $\begin{array}{l}\text { Audit Committee } \\
\text { Effectiveness }\end{array}$ & $\begin{array}{l}\text { A score that takes the value three if the } \mathrm{AC} \text { of the firm } \mathrm{i} \text { and the year } \mathrm{t} \text {, consists of } \\
\text { fully independent members, with at least three members, one of whom is a financial } \\
\text { expert, and holds at least three meetings a year, and less if any of the conditions } \\
\text { above are missing. }\end{array}$ \\
\hline Statown it & State Ownership & $\begin{array}{l}\text { The ratio of shares held by the Saudi government or any of its agencies to the total } \\
\text { number of outstanding shares of the firm } i \text { and the year } t \text {. }\end{array}$ \\
\hline Instown it & $\begin{array}{l}\text { Institutional } \\
\text { Ownership }\end{array}$ & $\begin{array}{l}\text { The ratio of shares held by institutional investors to the total number of outstanding } \\
\text { shares of the firm } i \text { and the year } t \text {. }\end{array}$ \\
\hline Big4 it & Auditor type & $\begin{array}{l}\text { A dummy variable that takes the value one if the firm i during the year } t \text { is audited } \\
\text { by one of the big- } 4 \text { auditors, and zero otherwise. }\end{array}$ \\
\hline
\end{tabular}

\section{Corporate Characteristics}

Complex it Firm complexity Number of subsidiaries of the firm i during the year $\mathrm{t}$.

\begin{tabular}{lcl}
\hline Levrg it & Firm Leverage & The total debts divided by the total assets of the firm $\mathrm{i}$ and the year $\mathrm{t}$. \\
\hline Size it & Firm Size & The natural logarithm of total assets of the firm $\mathrm{i}$ and the year $\mathrm{t}$. \\
\hline Age it & Firm age & The natural logarithm of period from first establishment of the firm i to the year t. \\
\hline ROA it & Firm profitability & The ratio of total net income to the total assets of the firm i and the year t.
\end{tabular}


Table 3: Descriptive Statistics

\begin{tabular}{|c|c|c|c|c|}
\hline Variable & Mean & Min & Max & Median \\
\hline $\mathrm{RD}$ it & 12.59 & 0.00 & 36.00 & 11.00 \\
\hline Brdindp it & 0.58 & 0.00 & 1.00 & 0.56 \\
\hline Dual it $_{\text {it }}$ & 0.89 & 0.00 & 1.00 & 1.00 \\
\hline ACscore $_{\text {it }}$ & 1.14 & 0.00 & 3.00 & 1.00 \\
\hline Statown it & 0.13 & 0.00 & 0.89 & 0.09 \\
\hline Instown it & 0.13 & 0.00 & 0.66 & 0.00 \\
\hline Big4 it & 0.68 & 0.00 & 1.00 & 1.00 \\
\hline Complex it & 7.71 & 0.00 & 70.00 & 3.00 \\
\hline Levrg it & 0.10 & 0.00 & 0.62 & 0.03 \\
\hline Size $_{\text {it }}$ & 9.27 & 7.18 & 11.10 & 9.31 \\
\hline Age $_{\text {it }}$ & 1.23 & 0.00 & 1.75 & 1.28 \\
\hline ROA it & 0.09 & -0.11 & 0.33 & 0.08 \\
\hline
\end{tabular}


Table 4: Pearson Correlation Results

\begin{tabular}{|c|c|c|c|c|c|c|c|c|c|c|c|c|}
\hline & RD & BRDINDP & DUAL & ACSCOR & STATOWN & INSTOWN & BIG4 & COMPLEX & LEVRG & SIZE & AGE & ROA \\
\hline RD & 1.000 & & & & & & & & & & & \\
\hline BRDINDP & $0.4607^{*}$ & 1.000 & & & & & & & & & & \\
\hline ACSCOR & $0.6701^{*}$ & $0.5196^{*}$ & 0.067 & 1.000 & & & & & & & & \\
\hline STATOWN & $0.6162^{*}$ & $0.2704^{*}$ & $0.4125^{*}$ & $0.2682^{*}$ & 1.000 & & & & & & & \\
\hline INSTOWN & $0.1778 *$ & 0.010 & 0.029 & $0.1588^{*}$ & 0.026 & 1.000 & & & & & & \\
\hline BIG4 & $0.1234^{*}$ & -0.079 & 0.011 & 0.077 & 0.088 & $0.1879 *$ & 1.000 & & & & & \\
\hline COMPLEX & $0.4416^{*}$ & $0.2440 *$ & $0.1862 *$ & $0.4646 *$ & $0.1567^{*}$ & 0.072 & $0.1464^{*}$ & 1.000 & & & & \\
\hline LEVRG & $0.1363^{*}$ & 0.043 & -0.061 & $0.1664^{*}$ & 0.077 & $0.1058^{*}$ & 0.2949* & $0.2284^{*}$ & 1.000 & & & \\
\hline SIZE & $0.5981^{*}$ & $0.2862 *$ & $0.2786^{*}$ & $0.4438^{*}$ & $0.3912 *$ & $0.1054 *$ & $0.2520^{*}$ & $0.4653^{*}$ & $0.3069 *$ & 1.000 & & \\
\hline AGE & $0.2817^{*}$ & $0.3836^{*}$ & $0.1303^{*}$ & $0.2786^{*}$ & $0.1935^{*}$ & -0.060 & $-0.1296 *$ & $0.3150^{*}$ & -0.025 & 0.085 & 1.000 & \\
\hline ROA & $0.3205^{*}$ & $0.1527^{*}$ & $0.2599^{*}$ & $0.1674^{*}$ & $0.3521^{*}$ & 0.084 & $0.2004^{*}$ & $0.2826^{*}$ & $0.1157^{*}$ & $0.2050^{*}$ & $0.3648^{*}$ & 1.000 \\
\hline
\end{tabular}


Table 5: The Regression Results

\begin{tabular}{|c|c|c|c|c|c|}
\hline Symbol & Definition & & & $\begin{array}{c}\mathrm{t}- \\
\text { statistic }\end{array}$ & $P>t$ \\
\hline Cons. & Model Constant & $\beta 0$ & -24.76 & -0.07 & 0.00 \\
\hline Brdindp & Board Independence & B1 & 0.72 & 0.50 & 0.62 \\
\hline Dual & Dual Role & B2 & 2.78 & 3.31 & $\mathbf{0 . 0 0}$ \\
\hline ACscore & Audit Committee Effectiveness & B3 & 3.03 & 4.18 & 0.00 \\
\hline Statown & State Ownership & B4 & 2.62 & 3.28 & $\mathbf{0 . 0 0}$ \\
\hline Instown & Institutional Ownership & B5 & 1.60 & 1.04 & 0.30 \\
\hline Big4 & Auditor Type & B6 & 0.83 & 1.31 & 0.19 \\
\hline Complex & Firm Complexity & B7 & 0.13 & 4.09 & 0.00 \\
\hline Levrg & Firm Leverage & B8 & -0.55 & -0.26 & 0.80 \\
\hline Size & Firm Size & B9 & 1.21 & 2.33 & 0.02 \\
\hline Age & Firm Age & $\beta 10$ & -0.19 & -0.26 & 0.79 \\
\hline ROA & Firm Profitability & $\beta 11$ & 6.55 & 1.96 & 0.05 \\
\hline
\end{tabular}

\section{Extra Statistics}

$\begin{array}{lccc}\mathbf{F}(\mathbf{1 1}, \mathbf{3 9 6})= & \text { Prof }>\mathrm{F}= & \text { Adj. } \mathrm{R}-\mathrm{sq}= & \text { No. of Observations }= \\ \mathbf{6 1 . 2 8} & 0.000 & 0.62 & 408\end{array}$

*Significant at $10 \%, * *$ Significant at $5 \%, * * *$ Significant at $1 \%$, bold variables are statistically significant. 